\section{Research Reports}

\section{Effects of Light, Soil Moisture, and Nutrition on Greenhouse Propagation of Twinflower}

\author{
Jonathan Foster ${ }^{1,3}$, Stephanie Burnett ${ }^{1}$, and Lois Stack ${ }^{2}$
}

AdDITIONAL INDEX wORDs. Linnaea bovealis, moisture sensor, daily light integral

Summary. Twinflower (Linnaea borealis) is an understory subshrub native to northern regions of North America, Europe, and Asia. Some growers report that this native plant is difficult to propagate. Although twinflower prefers partial shade and grows in areas with naturally variable moisture, there has been no greenhouse propagation work testing the impact of light or soil moisture conditions on root development of this plant or whether fertilizer impacts root development or root:shoot ratios during propagation. The goal of the first experiment was to propagate twinflower under a variety of daily light integrals (DLI) - 27.6, 14.4, or $5.8 \mathrm{~mol} \cdot \mathrm{m}^{-2} \cdot \mathrm{d}^{-1}$ - and soil volumetric water content values $(\theta=$ volume of water $\div$ volume of soil $) 0.30,0.35,0.40$, and $0.45 \mathrm{~L} \cdot \mathrm{L}^{-1}$, both parameters aimed at reproducing a range of natural conditions. The largest roots were grown at DLIs of 5.8 and $14.4 \mathrm{~mol} \cdot \mathrm{m}^{-2} \cdot \mathrm{d}^{-1}$ and $\theta$ values of 0.30 and $0.35 \mathrm{~L} \cdot \mathrm{L}^{-1}$. In the second experiment, twinflower plants were grown in substrates with $0,2.1$, or $5.0 \mathrm{~g} \cdot \mathrm{L}^{-1}$ of incorporated controlled-release fertilizer $(14 \mathrm{~N}-6.1 \mathrm{P}-11.6 \mathrm{~K})$. Root and shoot dry weight increased at both treatment rates. The relative percentages of nitrogen, phosphorus, and potassium, and the total concentrations of manganese in parts per million, increased in foliage, as well. In both experiments, the source of cuttings impacted results. In the first experiment, cuttings taken from the source that was in the most light were least likely to survive ( $26 \%$ survival rate) compared with cuttings taken from stock plants growing in partial shade (65\% or $82 \%$ survival rates, by site). In the second experiment, cuttings taken from source plants that were most intensively managed for removal of weeds and competing plants had the highest survival rate and the greatest shoot and root dry weight. We recommend propagating twinflower with moderate rates of fertility (i.e., $2.1 \mathrm{~g} \cdot \mathrm{L}^{-1}$ of incorporated controlled-release fertilizer) under some shade $(5.8-14.4 \mathrm{DLI})$ and a moderate $\theta\left(0.30-0.35 \mathrm{~L} \cdot \mathrm{L}^{-1}\right)$.

$\mathrm{T}$ Wwinflower is a spreading, evergreen, circumpolar groundcover plant native to North America, Europe, and Asia (Sobey and Barkhouse, 1977). The species is declining in some regions of its native habitat and is considered threatened or endangered by eight U.S. states at the time of this publication (Tsaryk and Malynovs'kyi, 1995; U.S. Department of Agriculture, 2014; Wilcock, 2001). Twinflower's subtle but attractive foliage and pale pink inflorescences appeal to homeowners and naturalists
(Backlund and Pyck, 1998; Jacobs et al., 2010; Scobie and Wilcock, 2009), and the plant offers commercial and residential potential as a native, spreading groundcover for partly shaded landscape spaces (Wilcock, 2001). However, northern New England commercial and conservation growers report inconsistent success with cutting propagation, as well as labor-intensive and cost-ineffective methods (such as hand watering and daily bagging and opening for humidity control) used to improve results (W. Cullina, personal communication; S. Green, personal communication; M. Navazio, personal communication).

As a clonal plant, twinflower grows via spreading stolons. This growth habit, twinflower's limited sexual reproductive mechanism (Barrett and Helenurm, 1987; Ericksson, 1992; Scobie and Wilcock, 2009), and its limited commercial value preclude more expensive techniques such as tissue culture, and propagation via cuttings has been the primary viable method used in horticultural production. Standard horticultural cutting propagation protocols emphasize shaded, moist environments to prevent excessive transpiration and promote turgor (Grange and Loach, 1983; Hartmann et al., 2011), but these conditions have resulted in problems with root and stem rot for regional twinflower propagators (S. Green, personal communication; M. Navazio, personal communication).

Data have indicated improved rooting rates in other species with increasing DLI under mist irrigation systems (Lopez and Runkle, 2008). Increased light intensity has caused notable shoot growth and branching in twinflower (Chavez and Macdonald, 2010; Ericksson, 1988, 1992; Niva et al., 2006) and other clonal, stoloniferous species (de Kroon and Hutchings, 1995; Dong and Pierdominici, 1995). Twinflower root growth in natural settings is generally poor, although

\begin{tabular}{llll}
\hline $\begin{array}{l}\text { Units } \\
\text { To convert U.S. to SI, } \\
\text { multiply by }\end{array}$ & U.S. unit & SI unit & $\begin{array}{l}\text { To convert SI to U.S., } \\
\text { multiply by }\end{array}$ \\
\hline 10 & $\%$ & $\mathrm{~g} \cdot \mathrm{L}^{-1}$ & 0.1 \\
29.5735 & $\mathrm{fl} \mathrm{oz}$ & $\mathrm{mL}$ & 0.0338 \\
0.3048 & $\mathrm{ft}$ & $\mathrm{m}$ & 3.2808 \\
0.0929 & $\mathrm{ft}^{2}$ & $\mathrm{~m}^{2}$ & 10.7639 \\
3.7854 & $\mathrm{gal}$ & $\mathrm{L}$ & 0.2642 \\
2.54 & inch $(\mathrm{es})$ & $\mathrm{cm}$ & 0.3937 \\
28.350 & $\mathrm{oz}$ & $\mathrm{mg}$ & $3.5274 \times 10^{-5}$ \\
1 & $\mathrm{ppm}$ & $\mathrm{mg} \cdot \mathrm{L}^{-1}$ & 1 \\
$\left({ }^{\circ} \mathrm{F}-32\right) \div 1.8$ & ${ }^{\circ} \mathrm{F}$ & ${ }^{\circ} \mathrm{C}$ & $\left({ }^{\circ} \mathrm{C} \times 1.8\right)+32$
\end{tabular}


this may be a result of ample moisture in shaded conditions where light is the limiting resource (Brouwer, 1983) or it could result from water resource sharing among clonal ramets (Alpert and Mooney, 1986; Chavez and Macdonald, 2010; Stuefer et al., 1994, 1996). Accordingly, Niva et al. (2006) found that decreased water alone had no effect on twinflower's stolon architecture, but decreased water in conjunction with increased light intensity decreased its root:shoot ratio.

Little work has explored the impact of soil volumetric water content on root dry weight during propagation. Most of the research that has been conducted was done before low-cost, precise soil moisture sensors became available. For plants that have been researched previously in horticultural settings, even though, greater soil moisture generally resulted in greater root development. For example, chrysanthemum (Dendranthema $\times$ morifolium) cuttings propagated in greenhouses produced the most roots when they were grown in a medium with the highest water content (Geneve et al., 2004). Volumetric water content as low as $0.1-0.2 \mathrm{~L} \cdot \mathrm{L}^{-1}$ for lavender (Lavandula angustifolia) and 0.2$0.3 \mathrm{~L} \cdot \mathrm{L}^{-1}$ for gardenia (Gardenia jasminoides) has been shown to negatively impact plant mortality and quality (Bayer et al., 2015; Zhen and Burnett, 2015).

Soil in the boreal forest that serves as twinflower's primary habitat tends to be acidic and low in nutrient

\footnotetext{
Funding for this research was provided by a Maine Agriculture Center Horticulture Research Grant and U.S. Department of Agriculture National Institute of Food and Agriculture Multistate Hatch project NE1335 (accession number ME0-31401). Any opinions, findings, conclusions, or recommendations expressed in this publication are those of the authors and do not necessarily reflect the view of the National Institute of Food and Agriculture (NIFA) or the U.S. Department of Agriculture (USDA).

Maine Agriculture and Forestry Experiment Station Publication \#3529.

We thank Van Berkum Nursery, Allison Dibble, Joshua Young, and Jan MacIntyre for their assistance in sourcing propagative material. We appreciate the technical assistance of Bradly Libby and Shuyang Zhen. Thank you to Michael Day for his helpful comments on an early draft of this manuscript.

${ }^{1}$ School of Food and Agriculture, University of Maine, 5722 Deering Hall, Orono, ME 04469

${ }^{2}$ University of Maine Cooperative Extension, 495 College Avenue, Orono, ME 04473

${ }^{3}$ Corresponding author. E-mail: jjfoster2003@alum.
} northwestern.edu.

doi: 10.21273/HORTTECH03685-17 availability because of climate, high organic matter, low organic decomposition rates, and the soil acidification effects of moss and coniferous canopies (Bonan and Shugart, 1989; Hobbie et al., 2002). However, it is unknown if increased fertility during propagation would impact rooting. Twinflower does not fit neatly into herbaceous or woody plant categories, and little greenhouse research has been conducted on it; as a result, there was scarce information available that seemed relevant to our study.

Previous research demonstrates that rooting may be impacted by a variety of environmental factors, including light, substrate moisture, and nutrient concentration. There has been little research on the propagation of twinflower, in particular how the propagation environment will impact rooting. To develop an effective greenhouse propagation protocol for twinflower, we conducted two experiments. In our first experiment, we determined effective DLI and $\theta$ levels for propagation. Having identified the most successful DLI and $\theta$ regimens from those experimentally tested and applying those effective parameters, our second objective was to evaluate the extent to which preplant incorporated fertilizer influences root and shoot growth in twinflower. Results would complete the third standard component (along with light and water) of manipulation of the greenhouse production environment and yield an effective propagation protocol for twinflower.

\section{Materials and methods}

Expt. 1: Light and $\boldsymbol{\theta}$. Twelve separate propagation boxes, $3 \times 3 \times 3 \mathrm{ft}$, were constructed from 0.5 -inch polyvinyl chloride tubing on adjacent wire mesh benches in a triple-layer polycarbonate greenhouse. Four of these boxes were located on each greenhouse bench (dimensions of $14 \times 3 \times 3 \mathrm{ft}$ ). Clear polyethylene sheets sealed off boxes and benches from each other to prevent cross-contamination between irrigation treatments. The full sunlight plot was also sealed by polyethylene sheeting on the ends, and a full sheet was draped along the southern face to ensure proper fog containment. The tops and bottoms of all systems were left open for ventilation and drainage.

Irrigation was provided using a capacitance sensor-automated fog system that was a variation of the sensor-automated drip irrigation system Nemali and van Iersel (2006) designed. Cuttings were propagated under fog nozzles (CoolNet Nozzles; Netafim, Fresno, CA) connected to pressure compensated emitters (65 psi; Netafim). They were turned off and on based on $\theta$ readings from capacitance soil sensors (EC-5; Decagon Devices, Pullman, WA) that were connected to a datalogger (CR-10X; Campbell Scientific, Logan, UT). One randomly selected plant container per subplot contained such a sensor, which tested voltage that passed through the medium once per minute. Sensors were inserted at a $45^{\circ}$ angle in as central a location as could be managed without interfering with propagules. The sensor conveyed voltage information to the datalogger, where it was converted to $\theta$ using a substrate-specific calibration $\left(\theta=2.232 \mathrm{e}^{-1}+1.359 \times\right.$ voltage $1.099 \times$ voltage $\left.^{2} ; R^{2}=0.99\right)$ that was experimentally determined before the experiment began. When the $\theta$ registered below the preprogrammed set points, solenoid valves (24-V AC; Hunter Industries, San Marcos, CA) connected to a relay driver (SDM16-AC; Campbell Scientific) opened to provide overhead fog irrigation via two nozzles per subplot. The volume of water discharged by each fog nozzle per activation was $3.8 \mathrm{fl} \mathrm{oz}$ over $10 \mathrm{~s}$ of irrigation. No published values for $\theta$ set points were available for twinflower or any closely related plants, so treatments offering a range of moisture levels emulating twinflower's natural conditions were selected based on our calibration equation: one set point high in the calibration curve, one low, and two near the midline: $0.30,0.35,0.40$, and $0.45 \mathrm{~L} \cdot \mathrm{L}^{-1}$

Light treatments were provided using a shadecloth to approximate a range of light conditions in which twinflower may be found in its native habitat, as well as to reflect reasonable production environments used by regional growers. Each bench was covered with $0 \%, 30 \%$, or $60 \%$ mylar shadecloth. Incoming photosynthetically active radiation $(P A R)$ was measured via three quantum sensors (model QSO-S; Apogee, Logan, UT), located centrally on each of the three benches and connected to the datalogger. Instantaneous light levels 
$\left(\mu \mathrm{mol} \cdot \mathrm{m}^{-2} \cdot \mathrm{s}^{-1}\right)$ were measured every 5 min throughout the course of the experiment. Average DLI totals received over the course of the study were $27.6 \mathrm{~mol} \cdot \mathrm{m}^{-2} \cdot \mathrm{d}^{-1}$ for the full sun bench, $14.4 \mathrm{~mol} \cdot \mathrm{m}^{-2} \cdot \mathrm{d}^{-1}$ for the $30 \%$ shade bench, and $5.8 \mathrm{~mol} \cdot \mathrm{m}^{-2} \cdot \mathrm{d}^{-1}$ for the $60 \%$ shade bench.

To avoid jeopardizing any single stand of twinflower by overharvesting, we obtained plant material for the experiment from three sources. Sixty cuttings were taken from a partly shady, natural stand located on a private property in Brooklin, ME (Source 1). This stand was minimally managed by the property owner, with some effort to clear competing plants along the stand border, but without fertilizer or other chemical applications. A large, partly shady, unmanaged natural stand in the University of Maine Forest, Orono, ME (Source 2 ), supplied 120 cuttings. A regional commercial grower (Source 3) supplied a flat of new plants from rooted cuttings, from which we harvested 60 cuttings. Stock plants had grown in partly shaded conditions until a severe weather event took down the canopy and put the site in full sun.

Source 3 plants were acquired several weeks before the others, because of logistics and timing, and were grown during that time in a triple-layer polycarbonate greenhouse in their original 72-cell flat on a mist bench where mist was turned on based on substrate moisture levels measured with a soil moisture sensor (SM200; Delta-T Devices, Cambridge, UK) connected to an irrigation controller (MoistureClik IL200MC; Dynamax, Houston, TX). Source 2 cuttings were harvested the morning they were stuck and stored briefly inside an externally cooled, misted plastic bag. Source l cuttings were harvested the morning before sticking, stored similarly to the Source 2 cuttings during transport, and thereafter stored in a floral cooler at a temperature of $6{ }^{\circ} \mathrm{C}$ until needed. All cuttings were stuck within 24-32 h of harvest from the parent plant, in keeping with the consensus for handling cuttings (W. Cullina, personal communication; Gorman and Roller, 2009; S. Green, personal communication; Luna et al., 2008; University of Washington, 2009).

Two-node cuttings (about 1.25 inches long) were taken from vegetative side shoots of individual twinflower ramets. Each selection was cut on a slant below the second fully developed node below the apical meristem (Hartmann et al., 2011), dusted in rooting hormone $(0.3 \%$ indole- 3 -butyric acid; Hormodin \#2; OHP, Mainland, PA), tapped gently to remove excess powder, placed into a dibbled hole, and firmed in gently. A third node with foliage was sometimes included at the base of the cutting if the topmost, emergent node was not yet fully developed and its leaves not fully expanded.

Cuttings were planted in open, $16 \times 16 \times 5$-inch containers, filled with $10.4 \mathrm{~L}$ of commercial germination mix containing fine peat, fine perlite, vermiculite, dolomitic lime, and a starter nutrient charge with gypsum (Fafard Super-Fine Germination Mix; Sun Gro, Agawam, MA). Each container held five cuttings, and there were four containers for each $\theta$ and light combination. Each individual container held cuttings from a single source. In each propagation box, all three sources were represented (two containers with cuttings from source 2 ). The experiment was a $3 \times 3$ $\times 4$ factorial design with three light treatments, three sources, and four $\theta$ treatment levels. $\theta$ treatments were randomized underneath shade structure, and the source was randomized within each propagation box.

The experiment began on 14 July 2012, and plants were harvested on 5 Sept. 2012. At that time, substrate was washed from roots by dunking and manual brushing, and survival rates and average length of the longest root were calculated. Survival rates by source were acquired by dividing living plants at harvest by the total number of cuttings stuck. All roots were removed from plants and dried for 1 week in a soil drying room at $70{ }^{\circ} \mathrm{C}$, after which root dry weight was measured.

Data were analyzed using general linear models in SAS (version 9.3; SAS Institute, Cary, NC) for main effects and interactions. Treatments were compared by Fisher's least significant difference means separation analysis, the Shapiro-Wilk test was used to confirm assumptions of normality, Leven's test was used to confirm equality of variance, and LSMeans in SAS (version 9.3) was used to analyze interactions. Results were considered significant at $P \leq$ 0.05 .

Expt. 2: Fertility. The same 12 propagation boxes from Expt. 1 were placed on three adjacent benches in the same greenhouse. As described previously, clear sheeting was used to separate benches and propagation boxes. All cuttings were grown under the light treatment (30\% shade cover) and $\theta$ level $\left(0.35 \mathrm{~L} \cdot \mathrm{L}^{-1}\right)$ determined to be most successful in Expt. 1. $\theta$ was controlled using a capacitance sensorautomated fog system, as described. Incoming $P A R$ was measured by one quantum sensor on each bench, and DLI was calculated from this information as described previously. Throughout Expt. 2, cuttings received an average DLI of $10.6 \mathrm{~mol} \cdot \mathrm{m}^{-2} \cdot \mathrm{d}^{-1}$. Differences in average DLI between experiments is most likely due to seasonal and weather variations.

Twinflower cuttings were taken from Source l (60 cuttings) and Source 2 (120 cuttings) from the previous experiment. Cuttings were also obtained from another minimally managed, shady natural stand [60 cuttings (Source 4)]. The site's owner manages the plant stand only by hand-weeding, to prevent encroachment by surrounding species. All cuttings were planted in $10.4 \mathrm{~L}$ of $1: 1$ peat:fine grade vermiculite substrate in 48 of the deep trays used in Expt. 1 . There were three rates of $14 \mathrm{~N}-$ 6.1P-11.6K controlled-release fertilizer (Scotts, Marysville, $\mathrm{OH}$ ) incorporated in the substrate, with 12 trays at each rate: $0,2.1$, or $5.0 \mathrm{~g} \cdot \mathrm{L}^{-1}$. The two treatment rates are based on the manufacturer's recommended application rate for low $\left(2.1 \mathrm{~g} \cdot \mathrm{L}^{-1}\right)$ and medium $(5.0$ $\left.\mathrm{g} \cdot \mathrm{L}^{-1}\right)$ rates of fertilizing. Substrate was pre-wetted before sticking the plant material. The fertilizer and substrate were mixed using a concrete mixer.

The experiment ran from 1 July 2013 to 28 Aug. 2013, after which plants were harvested as in Expt. 1. The number of cutting nodes and maximum root length were measured and averaged by container. Shoot and root tissues were dried in a soil drying room for 1 week, then root and shoot dry weights were determined. We also calculated root:shoot ratios (root dry weight divided by shoot dry weight). Leaf tissue was analyzed using two primary methods at the University of Maine Analytical Laboratory, with samples pooled across sources because 
of the small plant size to obtain necessary minimum weight requirements for nutrient analysis. Total nitrogen was measured via combustion on carbon and nitrogen analyzer (C/N 2000; LECO Corp., St. Joseph, MI), whereas all other nutrients were measured using inductively coupled argon plasma spectrophotometry analysis on samples prepared using a dry ashing protocol. Tests measured the end of the experiment concentrations across treatments of total nitrogen, calcium, potassium, magnesium, phosphorus, aluminum, boron, copper, iron, manganese, and zinc, and statistical analysis evaluated differences among the nutrient levels by fertilizer treatment.

Treatments were arranged in a completely randomized, $3 \times 3$ factorial design with three fertilizer rates and three plant material sources. Data were analyzed using general linear models in SAS (version 9.3). Treatments were compared by Fisher's least significant difference means separation analysis, the Shapiro-Wilk test was used to confirm equality of variance, and LSMeans was used to analyze interactions. Results were considered significant at $P \leq 0.05$.

\section{Results and discussion}

Expt. 1: Light AND $\theta$. Survival rates of the cuttings varied by source; cuttings from Source 3 , the flat of professionally propagated plants, had significantly lower survival rates $(26 \%)$ compared with the other two sources [65\% for Source 1 and $82 \%$ for Source 2 (data not shown)]. For this reason, Source 3 was excluded from further analysis. The other two sources did not differ significantly, so those data were pooled. Source 3 stock plants were not shaded, whereas the other two stock plants were located under forest canopies. Shading of stock plants has impacted rooting of other species, including european hornbeam [Carpinus betulus (Maynard and Bassuk, 1992)], and it would be worthwhile to further explore the impacts of stock plant management on root quantity in a future experiment.

DLI alone did not significantly impact twinflower root dry weight (Table 1). Other researchers noted that herbaceous plants grow more roots and generate higher root biomass under a higher DLI (Currey et al., 2012; Lopez and Runkle,
2008). Although we did not find a direct effect of light, there was an interaction between light and water (Table 1). The greatest root dry weight overall was observed at $\theta$ of $0.30 \mathrm{~L} \cdot \mathrm{L}^{-1}$ and DLI of $5.8 \mathrm{~mol} \cdot \mathrm{m}^{-2} \cdot \mathrm{d}^{-1}$. By comparison, at DLI of $14.4 \mathrm{~mol} \cdot \mathrm{m}^{-2} \cdot \mathrm{d}^{-1}$, a $\theta$ of 0.30 to $0.35 \mathrm{~L} \cdot \mathrm{L}^{-1}$ resulted in the highest root dry weight within that light level. The lowest root dry weights were observed under low DLI and high $\theta$. For example, none of the cuttings grown at a DLI of 5.8 $\mathrm{mol} \cdot \mathrm{m}^{-2} \cdot \mathrm{d}^{-1}$ and $\theta$ of $0.45 \mathrm{~L} \cdot \mathrm{L}^{-1}$ survived. Root dry weights of surviving plants were significantly lower when plants were grown at a DLI of 14.4 or $5.8 \mathrm{~mol} \cdot \mathrm{m}^{-2} \cdot \mathrm{d}^{-1}$ and $\theta$ of $0.40 \mathrm{~L} \cdot \mathrm{L}^{-1}$ or higher. In the wild, twinflower grows in shaded environments, and as an understory plant, it competes for water with other plants (Locky et al., 2005; Rasmus et al., 2011; Talbot et al., 2010). By comparison, chrysanthemum plants grown at a variety of gravimetric water contents (i.e., measuring soil water content by weight rather than volume, and thus giving different figures from our $\theta$ values) from $25 \%$ to $250 \%$ were no different in size (Blom and Piott, 1992). Many greenhouse crops, such as gaura (Gaura lindhiemeri) increase growth when grown at a $\theta$ of $0.40 \mathrm{~L} \cdot \mathrm{L}^{-1}$ (Burnett and van Iersel, 2008).

This research provides promising recommendations that twinflower propagators should be rooting plants in drier conditions that are lightly shaded. There may be other plants that would benefit from greater $\theta$ control during propagation, especially considering the expense of greenhouse irrigation in professional operations. It would be of interest in the future to develop a commercially viable method for controlling $\theta$ during propagation. Our current system can only be used in large, open flats because capacitance sensors are too large to fit into a standard propagation tray. Aerial sensors, such as a leaf wetness sensor (LWS sensor; Decagon Devices), may be one option for growers who wish to have greater control over wetness in the propagation environment.

Expt. 2: Fertility. Both fertilizer and plant source affected twinflower root dry weight, and there was a significant interaction between those two factors (Tables 2 and 3 ). Both rates of fertilizer increased final root dry weight compared with controls, and the greatest root dry weight was observed when $5.0 \mathrm{~g} \cdot \mathrm{L}^{-1}$ of controlledrelease fertilizer was incorporated into substrates. Hartmann et al. (2011) reported that topdressing with $18 \mathrm{~N}-$ $2.6 \mathrm{P}-10 \mathrm{~K}$ fertilizer increased root production in japanese privet (Ligustrum japonicum), but notes that supplemental nutrition does not promote root initiation, but rather root development after initiation.

In the second experiment, Source 3 was not used for cuttings, and cutting survival was high for all other sources. However, morphology of plants grown

Table 1. Twinflower was propagated at three daily light integrals (DLI) and four volumetric water content $(\theta=$ volume of water $\div$ volume of soil $)$ levels to observe their effects on root dry weight. The experimental design was factorial; as main effects, DLI was not significant; $\theta$ was significant $(P=0.0001)$, and the interaction between DLI and $\theta$ was significant $(P=0.0199)$.

\begin{tabular}{lcc}
\hline DLI $\left(\mathbf{m o l} \cdot \mathbf{m}^{-2} \cdot \mathbf{d}^{-\mathbf{1}}\right)$ & $\boldsymbol{\theta}\left(\mathbf{L} \cdot \mathbf{L}^{-\mathbf{1}}\right)^{\mathbf{z}}$ & Root dry wt $[\mathbf{m e a n} \pm \mathbf{s E}(\mathbf{m g})]^{\mathbf{z}}$ \\
\hline 27.6 & 0.30 & $34 \pm 4 \mathrm{~b}^{\mathrm{y}}$ \\
27.6 & 0.35 & $42 \pm 10 \mathrm{ab}$ \\
27.6 & 0.40 & $22 \pm 3 \mathrm{bc}$ \\
27.6 & 0.45 & $31 \pm 12 \mathrm{~b}$ \\
14.4 & 0.30 & $41 \pm 12 \mathrm{ab}$ \\
14.4 & 0.35 & $45 \pm 8 \mathrm{a}$ \\
14.4 & 0.40 & $33 \pm 7 \mathrm{~b}$ \\
14.4 & 0.45 & $16 \pm 7 \mathrm{c}$ \\
5.8 & 0.30 & $48 \pm 3 \mathrm{a}$ \\
5.8 & 0.35 & $30 \pm 9 \mathrm{~b}$ \\
5.8 & 0.40 & $16 \pm 7 \mathrm{c}$ \\
5.8 & 0.45 & Dead $^{\mathrm{x}}$ \\
\hline
\end{tabular}

${ }^{\mathrm{z}} 1 \mathrm{~L}=0.2642 \mathrm{gal}, \mathrm{l} \mathrm{mg}=3.5274 \times 10^{-5} \mathrm{oz}$

${ }^{\mathrm{y}}$ Data were analyzed for main effects and interactions using general linear models. Statistically different means $\left(P \leq 0.001, r^{2}=0.73\right)$ are represented by different letters; data were analyzed using least square mean comparisons. ${ }^{\mathrm{x}}$ No plants in this treatment survived. 
Table 2. The impact of cutting source, incorporation of $14 \mathrm{~N}-6.1 \mathrm{P}-11.6 \mathrm{~K}$ controlled-release fertilizer in substrates, and the interaction between those two factors on shoot dry weight, root:shoot, and number of stem nodes in greenhouse propagation of twinflower. Data were analyzed using general linear models and Fisher's least significant difference means separation analysis, and LSMeans in SAS (version 9.3; SAS Institute).

\begin{tabular}{|c|c|c|c|c|}
\hline & Root dry wt (mg) & Shoot dry wt (mg) & Root:shoot (ratio) & Stem nodes (no.) \\
\hline & \multicolumn{4}{|c|}{$($ Mean \pm SD $)$} \\
\hline Source ${ }^{y}$ & $P \leq 0.001^{\mathrm{x}}, r^{2}=0.77$ & $P \leq 0.004, r^{2}=0.67$ & $P \leq 0.05, r^{2}=0.67$ & NS \\
\hline 2 & 11 & $80 \pm 36 b$ & $0.17 \pm 0.06 \mathrm{~b}$ & $22.9 \pm 5.9$ \\
\hline 4 & 14 & $70 \pm 39 b$ & $0.21 \pm 0.06 \mathrm{a}$ & $27.4 \pm 5.4$ \\
\hline Fertilizer rate $\left(\mathrm{g} \cdot \mathrm{L}^{-1}\right)^{\mathrm{z}}$ & $P \leq 0.001, r^{2}=0.77$ & $P \leq 0.001, r^{2}=0.67$ & $P \leq 0.05, r^{2}=0.62$ & $P \leq 0.05, r^{2}=0.85$ \\
\hline 5.0 & 17 & $127 \pm 43 \mathrm{a}$ & $0.16 \pm 0.05 b$ & $12.7 \pm 6.0 \mathrm{a}$ \\
\hline$\underline{\text { Fertilizer } \times \text { source }}$ & $P \leq 0.004, r^{2}=0.77$ & NS & NS & NS \\
\hline
\end{tabular}

${ }^{\mathrm{z}} \mathrm{l} \mathrm{mg}=3.5274 \times 10^{-5} \mathrm{oz}, \mathrm{g} \cdot \mathrm{L}^{-1}=0.1 \%$.

${ }^{y}$ Source 1 was a managed suburban site, Source 2 was an unmanaged wild stand, and Source 4 was a minimally managed wild stand.

${ }^{x}$ Treatments were considered statistically significant at a $P \leq 0.05$. Ns represents nonsignificant treatments. Statistically distinct groups are represented by a, b, or c. Mean separation data for root dry weight are shown in Table 3.

Table 3. The interaction between cutting source and incorporation of $14 \mathrm{~N}-$ $6.1 \mathrm{P}-11.6 \mathrm{~K}$ controlled-release fertilizer in substrates on root dry weight of twinflower was significant based on general linear models LSMeans analysis in SAS (version 9.3; SAS Institute) $[P \leq 0.004$ (Table 2)]. Means separation analysis of each source and fertilizer combination was conducted in SAS using Fisher's least significant difference. Both source and fertilizer were significant $(P<0.0001$ for source and $P=0.0004$ for fertilizer $)$.

\begin{tabular}{|c|c|c|}
\hline Source & Fertilizer rate $\left(\mathrm{g} \cdot \mathrm{L}^{-1}\right)^{\mathrm{z}}$ & Root dry wt $[\text { mean } \pm \text { SD }(\mathrm{mg})]^{y}$ \\
\hline $1^{x}$ & 0 & $16 \pm 4 b^{w}$ \\
\hline 1 & 2.1 & $18 \pm 2 b$ \\
\hline 1 & 5.0 & $26 \pm 4 a$ \\
\hline 2 & 0 & $10 \pm 2 c$ \\
\hline 2 & 2.1 & $11 \pm 2 c$ \\
\hline 2 & 5.0 & $14 \pm 2 b c$ \\
\hline 4 & 0 & $10 \pm 2 \mathrm{c}$ \\
\hline 4 & 2.1 & $15 \pm 6 b$ \\
\hline 4 & 5.0 & $16 \pm 5 b$ \\
\hline \multicolumn{3}{|c|}{$\begin{array}{l}{ }^{\mathrm{z}} \text { Controlled-release fertilizer was incorporated into substrates at rates of } 0 \text { (control), } 2.1 \text {, or } 5.0 \mathrm{~g} \cdot \mathrm{L}^{-1} \\
\mathrm{l} \mathrm{g} \cdot \mathrm{L}^{-1}=0.1 \% \text {. } \\
\mathrm{y} 1 \mathrm{mg}=3.5274 \times 10^{-5} \mathrm{oz} \text {. } \\
{ }^{\mathrm{x}} \text { Source } 1 \text { was a managed suburban site, Source } 2 \text { was an unmanaged wild stand, and Source } 4 \text { was } \\
\text { a minimally managed wild stand. } \\
{ }^{w} \text { Different letters represent statistically distinct groups. }\end{array}$} \\
\hline
\end{tabular}

from cuttings taken from the sources used in experiment two differed ( $\mathrm{Ta}-$ ble 2$)$. The average root dry weight for Source $\mathrm{l}$ was $29.6 \mathrm{mg}, 45.2 \%$ higher than the Source 4 average of $13.5 \mathrm{mg}$, and $71.9 \%$ higher than the Source 2 average of $11.4 \mathrm{mg}$. Plants collected from Source 1 had higher shoot dry weights compared with those collected from the other two sources (Table 2). Furthermore, cuttings collected from Sources 1 and 4 resulted in plants with higher root: shoot ratios compared with cuttings taken from Source 2 (Table 2). In both experiments, light may have impacted rooting success as physical, physiological, and ontological conditions of stock plants are known to influence success of rooting cuttings from those sources (Hartmann et al., 2011; Larsen, 2014). The Source 1 site had optimal light and water conditions for twinflower. Light conditions may not have been as ideal at the other two sites. In addition, the site for Source 1 cuttings was managed to remove weeds and competing plants. The other two sites were not as intensively managed. The greatest rooting was observed when cuttings from Source 4 received the highest rate of fertilizer (Table 3 ).

Fertilizer significantly impacted shoot dry weight (Table 2). As with root dry weight, the greatest shoot dry weight was observed when $5.0 \mathrm{~g} \cdot \mathrm{L}^{-1}$ of fertilizer was incorporated into substrates (Table 2). Plants treated with the highest rate of fertilizer had 183.5\% greater shoot dry weight compared with the control. Similarly, Currey and Lopez (2014) observed that shoot dry weight of a variety of annuals, including summer snapdragon (Angelonia angustifolia), new guinea impatiens (Impatiens hawkeri), nemesia (Nemesia fruticans), zonal geranium (Pelargonium $\times$ bortorum), and petunia (Petunia $\times$ bybrida) increased when controlled-release fertilizer was incorporated into substrates. We also observed substantial stolon growth in many plants from this treatment. However, it is important to note that shoot growth increased proportionally greater compared with root growth when cuttings received fertilizer (Table 2). The root: shoot ratio was lower for twinflower that grew in substrates with any amount of fertilizer compared with controls.

Fertilizer significantly impacted the number of nodes (Table 2). Either 2.1 or $5.0 \mathrm{~g} \cdot \mathrm{L}^{-1}$ of CRF resulted in more nodes compared with cuttings grown in substrates with no fertilizer. Incorporating 5.0 $\mathrm{g} \cdot \mathrm{L}^{-1}$ fertilizer in substrates resulted in plants with an average node number per plant of 12.7 whereas the 2.1 rate yielded an average node number per plant of $11.2,264.1 \%$ greater and $220.3 \%$ greater, respectively, than the 3.5 average node number for control plants. Nitrogen, phosphorus, and potassium fertilizer has also been associated with increased node number in mallow (Corchorus olitorius) and cockscomb (Celosia argentea) 
(Makinde et al., 2011). Plant overall growth response to nitrogen fertilization has been shown to be species dependent, with some studies arguing that most landscape annuals require high nitrogen input to achieve maximum size (Shurberg et al., 2012), whereas other data have demonstrated no effect on posttransplant development of woody shrub seedlings (Shober et al., 2013).

Of the 11 nutrients analyzed during foliar analysis, measurements of only four nutrients significantly differed among treatments. These were nitrogen (total), phosphorus, potassium, and manganese (Table 4); nitrogen, phosphorus, and potassium results were reported as relative percentage, whereas the manganese measurement was a concentration in parts per million. All other nutrients returned insignificant results. For each of the four significantly increased nutrients, the jump from control to the $2.1 \mathrm{~g} \cdot \mathrm{L}^{-1}$ rate was significant, but there was no difference in concentration between plants fertilized with the 2.1 and $5.0 \mathrm{~g} \cdot \mathrm{L}^{-1}$ rates (data not shown). The rises in nitrogen, phosphorus, and potassium concentrations are unsurprising, given that they are the primary components of our experimental fertilizer. The reason for the manganese increase is unclear, but it may be related to $\mathrm{pH}$ of the substrate. Manganese uptake increases as $\mathrm{pH}$ moves away from neutral toward high or low $\mathrm{pH}$ (Taiz and Zeiger, 2010), and substrates heavily composed of peat tend to be acidic, particularly when fertilized (Nelson, 2003; Petrie and Jackson, 1984a). There have also been some data to suggest that certain formulations of nitrogen fertilizer along with manganese supplements significantly increase foliar manganese concentrations in barley (Hordeum vulgare) and oats (Avena sativa) (Petrie and Jackson, 1984b), so there may be an interaction between the two nutrients in our study, as well.

\section{Conclusions}

Twinflower root formation was improved both by controlling the environment of the propagules and adding fertilizer to substrates. The best rooting was observed when $\theta$ was 0.30 to 0.35 and DLI was 5.8 to $14.4 \mathrm{~mol} \cdot \mathrm{m}^{-2} \cdot \mathrm{d}^{-1}$. Adding either amount of controlled fertilizer resulted in cuttings with greater shoot and root growth. The largest plants grew in substrates with $5.0 \mathrm{~g} \cdot \mathrm{L}^{-1}$; however, there was no difference in foliar uptake of nutrients at this rate compared with $2.1 \mathrm{~g} \cdot \mathrm{L}^{-1}$. Observationally, we noted algae growing on the surface of substrates with $5.0 \mathrm{~g} \cdot \mathrm{L}^{-1}$ of fertilizer and substrates with the most fertilizer also seemed to have higher populations of fungus gnats (Bradysia coprophilia and Bradysia impatiens). Both conditions should be monitored by growers in commercial settings for production of high quality, saleable plants. In comparison with the other existing protocols, we found variable survival rates challenging, but our method effectively propagates a quality crop using minimal plant material. The existing research focuses predominantly on 12-inch cuttings, which are more likely to establish, but also potentially a huge impact to the stock plant, especially if it is a wild stand. The University of Washington, 2008, approach mentioned 1.2 to 2 -inch cuttings taking 5-10 years to develop stolons, but we had numerous plants already

Table 4. Effects of incorporation of $14 \mathrm{~N}-6.1 \mathrm{P}-11.6 \mathrm{~K}$ controlled-release fertilizer in substrates on foliar nutrient concentration at harvest in twinflower. Data were analyzed using general linear models and Fisher's least significant difference means separation analysis, and LSMeans in SAS (version 9.3; SAS Institute).

\begin{tabular}{lcccc}
\hline & $\mathbf{N}(\mathbf{p p m})^{\mathrm{y}}$ & $\mathbf{P}(\mathbf{p p m})$ & $\mathrm{K}(\mathbf{p p m})$ & $\mathrm{Mn}(\mathrm{ppm})$ \\
\cline { 2 - 5 } Rate $\left(\mathrm{g} \cdot \mathrm{L}^{-1}\right)^{\mathrm{z}}$ & \multicolumn{4}{c}{$($ Mean $\pm \mathrm{SD})$} \\
\hline 0 & $0.80 \pm 0.05$ & $0.06 \pm 0.01$ & $1.08 \pm 0.12$ & $57.1 \pm 3.9$ \\
2.1 & $1.81 \pm 0.35$ & $0.27 \pm 0.09$ & $1.86 \pm 0.41$ & $78.8 \pm 16$ \\
5.0 & $1.90 \pm 0.17$ & $0.29 \pm 0.04$ & $1.81 \pm 0.18$ & $84.5 \pm 7.35$ \\
& $P=0.0002^{\mathrm{x}}$ & $P=0.0006$ & $P=0.0041$ & $P=0.0119$ \\
& $r^{2}=0.89$ & $r^{2}=0.85$ & $r^{2}=0.75$ & $r^{2}=0.67$ \\
\hline
\end{tabular}

${ }^{\mathrm{z}} \mathrm{l} \mathrm{g} \cdot \mathrm{L}^{-1}=0.1 \%$.

${ }^{y}$ Plants were analyzed for foliar concentration of nitrogen $(\mathrm{N})$, phosphorus $(\mathrm{P})$, potassium $(\mathrm{K})$, calcium, magnesium $(\mathrm{Mn})$, aluminum, boron, copper, iron, manganese, and zinc concentrations; however, only those nutrients that were significantly different among treatments are shown; $1 \mathrm{ppm}=1 \mathrm{mg} \cdot \mathrm{L}^{-1}$.

${ }^{x}$ Totals were significant at $P \leq 0.05$. forming stolons in only 6 weeks. This paper should present an effective protocol using a more sustainable harvest technique.

In both the experiments, the source of cuttings impacted quality of rooting. Finding and maintaining high quality stock material can be challenging when working with threatened or endangered native plants. For example, one grower we talked with had reliable twinflower stock plants, but the environmental conditions for the plants were changed when a tornado destroyed many large trees in their nursery. The lack of consistency observed in cuttings that were taken from different stock plants emphasizes that producers of twinflower and other native plants should, if possible, maintain stock plants in desirable growing environments. Further research into the impact on propagule success of the timing of cutting acquisition-to consider both varying seasonal daylength and changing ecophysiological parameters-as well as the effects of light and water conditions on the plant's ontogenetic development could determine what environment for the twinflower stock plant results in better rooting for cuttings.

\section{Literature cited}

Alpert, P. and H.A. Mooney. 1986. Resource sharing among ramets in the clonal herb, Fragaria chiloensis. Oecologia 70:227-233.

Backlund, A. and N. Pyck. 1998. Diervillaceae and Linnaceae, two new families of caprifolioids. Taxon 47:657-661.

Barrett, S.C.H. and K. Helenurm. 1987. The reproductive biology of boreal forest herbs. I. Breeding systems and pollination. Can. J. Bot. 65:2036-2046.

Bayer, A., J. Ruter, and M.W. van Iersel. 2015. Automated irrigation control for improved growth and quality of Gardenia jasminoides 'Radicans' and 'August Beauty'. HortScience 50:78-84.

Blom, T.J. and B.D. Piott. 1992. Preplant moisture content and compaction of peatwool using two irrigation techniques on potted chrysanthemum. J. Amer. Soc. Hort. Sci. 117:220-223.

Bonan, G. and H. Shugart. 1989. Environmental factors and ecological processes in boreal forests. Annu. Rev. Ecol. Syst. 20:1-28.

Brouwer, R. 1983. Functional equilibrium: Sense or nonsense? Neth. J. Agr. Sci. 31:335-348. 
Burnett, S.E. and M.W. van Iersel. 2008. Morphology and irrigation efficiency of Gaura lindheimeri grown with capacitance-sensor controlled irrigation. HortScience 43:1555-1560.

Chavez, V. and S.E. Macdonald. 2010. Understory species interactions in mature boreal mixed-wood forests. Botany 88:912-922.

Currey, C. and R. Lopez. 2014. Controlledrelease fertilizer during cutting propagation affects growth and tissue nutrient concentrations of rooted cuttings of annual bedding plants. HortScience 49:152-159.

Currey, C.J., V.A. Hutchinson, and R.G. Lopez. 2012. Growth, morphology, and quality of rooted cuttings of several herbaceous annual bedding plants are influenced by photosynthetic DLI during root development. HortScience 47:25-30.

de Kroon, H. and M.J. Hutchings. 1995. Morphological plasticity in clonal plants: The foraging concept reconsidered. J. Ecol. 83:143-152.

Dong, M. and M.G. Pierdominici. 1995. Morphology and growth of stolons and rhizomes in three clonal grasses, as affected by different light supply. Vegetation 116:25-32.

Ericksson, O. 1988. Variation in growth rate in shoot populations of the clonal dwarf shrub Linnaea borealis. Holarct. Ecol. 11:259-266.

Ericksson, O. 1992. Population structure and dynamics of the clonal dwarf-shrub Linnaea borealis. J. Veg. Sci. 3:61-68.

Geneve, R.L., S.T. Kester, and J.W. Buxton. 2004. Capillary mats alter the water content in medium during mist propagation of Dendranthema. HortScience 39:584-587.

Gorman, R. and J. Roller. 2009. Twinflower. Native plants of Alaska: A guide for producing and cultivating. 14 Apr. 2014. <http://www.uaf.edu/files/ces/ publications-db/catalog/anr/HGA00232A.pdf>.

Grange, R.I. and K. Loach. 1983. The water economy of unrooted leafy cuttings. J. Hort. Sci. Biotechnol. 58:9-18.

Hartmann, H., D. Kester, F. Davies, and R. Geneve. 2011. Plant propagation: Principles and practices. 8 th ed. Prentice Hall, Upper Saddle River, NJ.

Hobbie, S., K. Nadelhoffer, and P. Hogberg. 2002. A synthesis: The role of nutrients as constraints on carbon balances in boreal and arctic regions. Plant Soil 242:163-170.
Jacobs, B., N. Pyck, and E. Smets. 2010. Phylogeny of the Linnaea clade: Are Abelia and Zabelia closely related? Mol. Phylogenet. Evol. 57:741-752.

Larsen, F.E. 2014. Propagating deciduous and evergreen shrubs, trees, and vines with stem cuttings. 31 Mar. 2014. <http://cru. cahe.wsu.edu / CEPublications / pnw0152/pnw0152.html>.

Locky, D., S. Bayley, and D. Vitt. 2005. The vegetational ecology of black spruce swamps, fens, and bogs in southern boreal Manitoba, Canada. Wetlands 25:564-582.

Lopez, R. and E. Runkle. 2008. Photosynthetic DLI during propagation influences rooting and growth of cuttings and subsequent development of New Guinea impatiens and petunia. HortScience 43:2052-2059.

Luna, T., J. Evans, D. Wick, K. Johnson, and R. Keating. 2008. Propagation protocol for production of container (plug) Linnaea borealis L. plants $800 \mathrm{~mL}$ containers. 22 June 2017. <https://npn. rngr.net/npn/propagation/protocols/ renderNPNProtocolDetails-PrintFormat>.

Makinde, S., M. Usilo, E. Makinde, and L. Ayeni. 2011. Comparative effect of mineral fertilizers and organic manures on growth, nutrient content and yield of Chorcorus olitorus and Celosia argentina. Res. J. Bot. 6:150-156.

Maynard, B.K. and N.L. Bassuk. 1992. Stock plant etiolation, shading, and banding effects on propagation of Carpinus betulus. J. Amer. Soc. Hort. Sci. 117:740-744.

Nelson, P. 2003. Greenhouse operation and management. 7th ed. Prentice Hall, Upper Saddle River, NJ.

Nemali, K.S. and M.W. van Iersel. 2006. An automated system for controlling drought stress and irrigation in potted plants. Sci. Hort. 110:292-297.

Niva, M., B.M. Svensson, and P.S. Karlsson. 2006. Effects of light and water availability on shoot dynamics of the stoloniferous plant Linnaea borealis. Ecoscience 13:318-323.

Petrie, S. and T. Jackson. 1984a. Effects of fertilization on soil solution $\mathrm{pH}$ and manganese concentration. Soil Sci. Soc. Amer. J. 48:315-318.

Petrie, S. and T. Jackson. 1984b. Effects of nitrogen fertilization on manganese concentration and yield of barley and oats. Soil Sci. Soc. Amer. J. 48:319-322.

Rasmus, S., R. Lundell, and T. Saarinen. 2011. Interactions between snow, canopy, and vegetation in a boreal coniferous forest. Plant Ecol. Divers. 4:55-65.
Scobie, A.R. and C.C. Wilcock. 2009. Limited mate availability decreases reproductive success of fragmented populations of Linnaea borealis, a rare, clonal self-incompatible plant. Ann. Bot. 103: 835-846.

Shober, A., K. Moore, N. West, C. Wiese, G. Hasing, G. Denny, and G. Knox. 2013. Growth and quality response of woody shrubs to nitrogen fertilization rates during landscape establishment in Florida. HortTechnology 23:898-904.

Shurberg, G., A. Shober, C. Wiese, G. Denny, G. Knox, K. Moore, and M. Giurcanu. 2012. Response of landscapegrown warm- and cool-season annuals to nitrogen fertilization at five rates. HortTechnology 22:368-375.

Sobey, D. and P. Barkhouse. 1977. The structure and rate of growth of the rhizomes of some forest herbs and dwarf shrubs of the New Brunswick-Nova Scotia border region. Can. Field Nat. 91:377-383.

Stuefer, J., H. During, and H. de Kroon. 1994. High benefits of clonal integration in two stoloniferous species, in response to heterogeneous light environments. J. Ecol. 82:311-518.

Stuefer, J.F., H. de Kroon, and H.J. During. 1996. Exploitation of environmental heterogeneity by spatial division of labor in a clonal plant. Funct. Ecol. 10:328-334.

Taiz, L. and E. Zeiger. 2010. Plant physiology. 5th ed. Sinauer Assoc., Sunderland, MA.

Talbot, S.S., W. Schofield, S.L. Talbot, and F. Daniels. 2010. Vegetation of eastern Unalaska Island, Aleutian Islands, Alaska. Botany 88:366-388.

Tsaryk, I.V. and K.A. Malynovs'kyi. 1995. Disintegration of Linnaea borealis L. population in stress situation. Ukr. Bot. J. 52:379-383. (in Ukrainian).

U.S. Department of Agriculture. 2014. The plants database. 22 Apr. 2014. <http://plants.usda.gov>.

University of Washington. 2009. Plant propagation protocol for Linnaea borealis L. ESRM 412 - Native plant propagation. 9 Sept. 2012. <http://courses.washington. edu/esrm412/protocols/LIBO3.pdf $>$.

Wilcock, C.C. 2001. Maintenance and recovery of rare clonal plants: The case of the twinflower (Linnaea borealis L.). Bot. J. Scotl. 54:121-131.

Zhen, S. and S. Burnett. 2015. Effects of substrate volumetric water content on english lavender morphology and photosynthesis. HortScience 50:909-915. 